ECONOMY AND FINANCE • VOL. 8. ISS. 2 • JUNE 2O21 • DOI: 10.33908/EF.2021.2.2

\title{
INCENTIVES IN THE GIG ECONOMY
}

Péter Kerényi ${ }^{1}$

\begin{abstract}
Fixed-term, contract-based employment is continuously spreading in the world. It has been given many names; in this paper it is termed the gig economy in the most comprehensive sense. We are going to present the basic features of the gig economy with special attention to short-term, incentive contracts affecting the relationship between employer and worker. In the gig economy employers use performance related wage to incentivise workers to work with the required intensity. By that incentive, employers also source out their risk to their workers whose wages and all their employment becomes uncertain. We are presenting in the paper that uncertainty arising out of short-term incentive contracts is the cause of many psychological and social ills.
\end{abstract}

JEL codes: Jo1, J31, J33, J38, J60, J81, J83

Keywords: gig economy, self-employment, platform economy, flexibility, incentives, risk, uncertainty, precarity

\section{INTRODUCTION}

As opposed to traditional long-term permanent employment, more and more employees have to accept project-based, fixed-term, short-term contracts. According to Katz-Krueger's (2019) estimation, in 2015 on the labour market of the US 15.8 per cent of employees worked in alternative work schedules (definite time contracts, temporary recruitment, on-demand work, zero-hour contracts, freelance), while 0.5 percent found employment through internet intermediaries. The numbers are similarly high in 13 European countries by Huws et al. (2019) or in Hungary by Berde (2020). Such untraditional work arrangements becoming increasingly prevalent are described in several ways both in the Hungarian and the international literature. We are going to use the term 'gig economy' in its most comprehensive sense.

1 Péter Kerényi, PhD student, Doctoral School of Economics, Business and Informatics of Corvinus University of Budapest. E-mail: peter.kerenyi@uni-corvinus.hu. 
In chapter 2, we are reviewing the background: we intend to clarify what exactly you mean by the gig economy, how it can be characterised and how those forms of work arrangement are connected to concepts such as crowdsourcing, work-ondemand via app, platform economy, temporary recruitment, free lancing, selfemployment, temporary agency work, etc. The number one call word of the gig economy is flexibility; we are going to briefly outline the advantages of flexibility for consumers, employers and workers in the gig economy. The relationship between employers and workers is in the focus of this analysis of the gig economy.

In chapter 3 , incentive contracts are introduced as a concept we believe fundamentally defines the relationship of the two parties. Incentive contracts, i.e. performance-related wage provide employers with an opportunity to really utilise the flexibility of the gig economy. Incentives, however, always go hand-in-hand with uncertainty and risk which mainly hit gig workers.

In chapter 4, we are reviewing the literature on the psychological and social challenges of the gig economy arising from the central motive of incentive-risk.

We are presenting our findings in chapter 5: the more vulnerable a worker is, the more effective the incentives are, and it seems more and more likely that gig economies are built on the exploitation of the vulnerable masses under the pretext of flexibility. It is indispensable that society review the modus operandi of the gig economy and regulate it properly.

Finally, the main ideas of the paper are summed up in chapter 6 .

\section{THE BACKGROUND OF THE GIG ECONOMY}

The gig economy is a work schedule or form of employment. Its most important criteria are that employees work based on contracts, for a fixed, usually short time frequently repeated. Work is often organised through an online platform. Some authors focus on that aspect, a digital platform, which efficiently collects and manages information, and describe the phenomenon with its help. The terms 'crowdsourcing' or 'crowdwork' are also used for that form of employment indicating, on the one hand, that the platform is in connection with a large crowd of workers, and on the other hand, the platform outsources several tasks and responsibilities of the traditional employer to the workers (e.g. Bergvall-KarrebornHowcroft, 2014). The terms 'platform economy' and 'work-on-demand via app' (e.g. De Stefano, 2015) can also be found. As opposed to this, the term 'gig economy' is used in studies focusing on short-term, repeated contract work rather than on online work arrangements (e.g. Ashford et al., 2018). The term 'gig economy' is also used in that wider sense in this paper. We believe it is not inevitable in the gig economy that work is organised via an online platform, it can take place through 
a traditional intermediary (e.g. placement services or temporary employment), or gig workers may sell their labour directly.

Who do you exactly mean when you talk about gig workers? To understand better how (in theory) flexible work arrangements work, let us look at two short simplified examples based on the above interpretation. A classical example of a gig worker is a bicycle food courier delivering orders received via an application (e.g. Drahokoupil-Piasna, 2019; Goods et al., 2019; Gregory, 2020). In the morning, our courier decides if they want to work on that day and if the answer is yes, how much and where. Based on that, they ride to the selected zone, log into the application and wait for orders. When an order is received, they will see what the task exactly is, where from and to the food must be delivered and how much they will get for the delivery. So, they can decide if they accept or reject the given delivery. When they get tired and do not want to continue working, they can log off the application indicating that no more orders are accepted. When they want to work again, they can log into the application again and indicate that orders are welcome.

You can find gig workers not only in low qualification jobs such as bicycle couriers but in positions requiring high qualifications - although they are usually termed free lancers, which sounds much nicer. Graphic artists can be an example, who may design the logo of a London pizzeria one day, they can work on creating the whole image of an US company for the next two months while drawing their own comics in the evenings. That form of employment is spreading in several different jobs. Broughton et al. (2018) collected the motivation and experiences of gig workers based on 150 interviews (the interviewees included workers in passenger and goods transport, creatives, highly qualified people, office staff, low qualification menial workers and skilled workers alike).

In our interpretation, the main features of the gig economy as opposed to traditional employment forms include contract employment, a well-defined period of employment and/or task in their contracts and performance-based wage, i.e. incentives. Gig workers must execute a well-defined task as fast as possible and/ or they must perform as much as possible within a definite period. Gig workers' wages depend directly on their monitored and controlled performance. Using the example of the bicycle courier, their wage depends on the distance covered during working hours. By simplifying the incentive, you will earn twice as much if you can pedal twice as fast or spend twice as much time on the street in a day. Or a graphic artist who also works at the weekend can accept more projects and will earn more.

Our concept of the gig economy is closest to free-lancing or self-employment as a kind of entrepreneurial activity. We, however, use the term 'gig economy' rather than the above terms, because the words 'free' and 'self' clearly carry a positive 
meaning, they indicate a kind of free will or independence, although the atypical forms of employment they designate are not so unambiguously positive. For instance, it is quite uncertain whether a taxi driver joins Uber on their independent decision rather than driven by an economic necessity. The same is indicated by the terms 'forced entrepreneurship' and 'bogus self-employment' (MacDonald-Giazitzoglu, 2019), that clearly carry a negative meaning, which we think are too strong to describe the phenomenon. Therefore, and in agreement with Tamás Gyulavári (Gyulavári, 2019), who proposed the term 'gig' because of its reference to occasional short-term employment, we are using the term 'gig' - initially used for performing artists - to indicate the form of work organisation discussed in this paper.

Work arrangements in the gig economy are highly flexible and easily adapted to changing needs. There are three players in the gig economy (e.g. Stewart-Stanford, 2017, Broughton et al., 2018): workers, consumers and intermediaries. It should be noted, however, that in line with our broad interpretation of the gig economy, you cannot clearly separate consumers and intermediaries at all times, and the two functions may overlap. Workers satisfy the needs of consumers by their labour. Intermediaries collect and process the information on the demand and supply of work and then make their arrangements. Although it is known that intermediaries are not employers in the legal sense in most countries, we shall term the work organisers 'employers' in this paper for the shake of simplicity. The gig economy, in fact, differs from traditional employment by the relationship between worker and employer, so we are focusing on the relationship of the two players with special attention to the impact of incentives.

\subsection{Consumers}

The gig economy is adapted to the changing needs of its consumers, which is reflected in the term 'on-demand job' used by many. Consumer feedback, the quality of services are important aspects of gig workers' performance-based wage, so consumers are provided with higher quality services. Price is another important factor for consumers. Since employers are in contact with masses of workers in the gig economy, there is competition, which makes services cheaper. You as a consumer would be pleased to be taken to the airport in an Uber taxi at half the price, would you not? A model by Cachon et al. present the added value to consumers in a gig economy. According to the model, the adaptation of the gig economy to demand and supply and flexible work schedules result in added value for consumers as opposed to traditional work arrangements (Cachon et al., 2017). 


\subsection{Employers/principals}

Employers making work arrangements in atypical types of employment outsource or pass on to their workers several tasks and risks traditionally borne by them. Performance-based wage, which is subject to the result produced by workers, passes on the uncertainty arising from the fluctuation of demand for consumption and, as a result, for on-demand jobs to the workers. When bicycle couriers are charged a fixed daily fee in return for logging into the platform, their employers are not much worried about a few days of lower turnover, because its result, i.e. low performance pay on low turnover hits the courier. Naturally, if it occurred frequently, there would be no workers to be charged, so employers also carry some risk indirectly. On the other hand, the risk will be insignificant as long as employers can reach masses of workers and can always find enough workers to be attracted. An employer in its mature life cycle that is able to collect and manage sufficient quantity of information will achieve added value in the gig economy compared to traditional employment.

\subsection{Workers/agents}

Flexible work arrangements or self-employment have several advantages for workers. Flexitime allows them to set up a balance between work and private life. The flexibility of the gig economy is valuable for workers caring for their children or elderly relatives - they can accept a gig when they have the time for it beside their other duties. Odd jobs can be fitted in pleasantly with the tasks of a university student. There are gig workers for whom freedom, the autonomy to control their life and work and being their own boss is important. Another advantage of gig work, in addition to flexibility, is it can be a nice way to supplement your salary. A well performing worker can actually achieve higher wage than their mates in traditional employment. Another attraction for young people out of school can be the work experience obtained in the gig economy, which can then help them finding a good job in the traditional economy. Those were the aspects emphasised by gig workers when asked about their motivation to participate in the gig economy in a study by Broughton et al. (2018) (flexibility, income, work experience). 


\section{Figure 1}

A schematic illustration of the three functions

(consumers, employers, workers) and their relationships

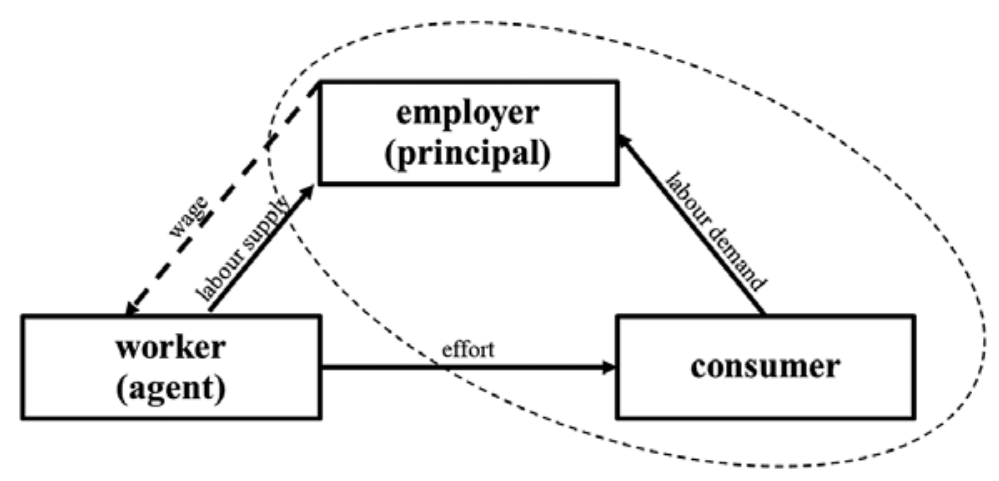

Source: compiled by author

In line with our broad interpretation of the gig economy, you cannot always clearly separate consumers and intermediaries and sometimes the two functions overlap.

It seems based on the above that all players benefit in a flexible gig economy. Cachon et al (2017) have come to a similar conclusion illustrated in their stylised model. In the next chapter we intend to refine that positive picture of the gig economy outlined earlier and review in detail incentive contracts defining the relationship of workers and employers and the different individual and social problems resulting from them.

\section{INCENTIVES AND RISK}

Incentives are becoming a marked concept in the world of work. Incentives are always of a financial nature, which is nothing other than performance-based wage. In this chapter, contract mechanisms defining the relationship of employers and workers are described.

The model frame principal-agent is a suitable approach to understand the relationship between employers and workers as well as the part played by incentives. The model can be traced back to Jensen and Meckling's agent theory, who used it to describe the relationship between company shareholders and managers: 
'We define an agency relationship as a contract under which one or more persons (the principals) engage another person (the agent) to perform some service on their behalf which involves delegating some decision-making authority to the agent' (Jensen and Meckling, 1976:308).

It is the principal who has primary control over the resources and the agent uses the resources and makes an effort. In our interpretation of the gig economy, the principal is the employer, and the agent is the worker while the resources are typically information. The employer transfer the resources, i.e. consumer information, to the worker and assigns them to meet the consumer's needs accordingly. In possession of the information transferred, the worker decides when and how they want to use the information and carry out the assignment. In the example of the bicycle courier, it means the employer forwards the worker the information, i.e. what the consumer's order is, where to it must be delivered from where and assigns the worker to carry it out. From then on, the worker uses the information and decides when, where and how fast to deliver the order.

\section{Table 1}

\section{Some examples of workers and employers in the gig economy}

\begin{tabular}{|c|c|c|}
\hline Worker (agent) & Employer (principal) & Studies \\
\hline Food courier & $\begin{array}{l}\text { platform (e.g. Netpincér GO, } \\
\text { Wolt, UberEATS, Deliveroo) }\end{array}$ & $\begin{array}{c}\text { Drahokoupil-Piasna (2019), } \\
\text { Goods et al. (2019), } \\
\text { Gregory (2020) }\end{array}$ \\
\hline Taxi driver & $\begin{array}{l}\text { platform (pl. Uber, } \\
\text { Lyft, Oszkár) }\end{array}$ & $\begin{array}{l}\text { Wu et al. (2019), } \\
\text { Berde-Kuncz (2020), } \\
\text { Berde-Tőkés (2020) }\end{array}$ \\
\hline Stand-up comedian & club promoter & $\begin{array}{l}\text { Butler-Stoyanova } \\
\text { Russel (2018) }\end{array}$ \\
\hline Office staff & $\begin{array}{l}\text { platform (pl. Amazon } \\
\text { Mechanical Turk) }\end{array}$ & $\begin{array}{l}\text { Bergvall-Kåreborn- } \\
\text { Howcroft (2014) }\end{array}$ \\
\hline Cabinet maker & platform (pl. TaskRabbit) & Prassl-Risak (2016) \\
\hline Researcher & university, research institute & $\begin{array}{l}\text { Ivancheva (2015), } \\
\text { Loveday (2018) }\end{array}$ \\
\hline
\end{tabular}

Naturally, employers' and workers' interests - the basis upon which they make decisions - are not necessarily the same, which leads to conflicts. Those conflicts are then solved by incentive contracts. Employers offer workers contracts transforming employers' interests into the adjudication criteria of workers, so workers, at the end, will make decisions meeting the employers' needs. What does it mean for our bicycle courier? The employer's interest is the courier should deliver as many orders as possible, i.e. to put as much effort into the work as possible. The 
courier's interest, on the other hand, is to earn as much as possible with as little effort - pedalling - as possible. From that, an optimum expected effort, a desired pedalling intensity is established for the employer, who wants to get the worker act accordingly. If the employer is able to directly observe the worker's effort, i.e. at what intensity the worker is pedalling, the employer may directly specify it in the contract. If the employer's interest requires the worker to pedal at $25 \mathrm{~km}$ an hour, he (the employer) will offer a contract stipulating the courier is paid only if their velocity is higher than that but will not be paid if it is lower even if the order is delivered. That type of direct control over work is termed 'employers' first-best solution in the principal-agent literature. It is characteristic in the gig economy that employers can control workers' efforts using high-tech sensors, algorithms and consumer rating systems, but they are still not able to have direct control in many situations. Then, the second-best solution is if employers offer their workers a share in the result of the work, which depends on the workers' effort, making them interested in bigger efforts. In a formula it looks as follows:

wage $=$ fixed pay + share $\times$ result.

If the fixed pay is nil, workers' wage depends on their result only. If the fixed pay is positive, workers receive a basic pay offering independent, safe income side by side with their result-based wage. If the fixed pay is negative, workers pay employers a fixed 'licence fee' for using the resources and, in return, receive a share of the result. An employer can assign their worker the total income arising from the work in return for a fixed licence fee. It is a structure similar to franchise and other licence agreements, where the licensee (the worker) pays the licence holder a fixed amount royalty/licence fee for the resources (e.g. information, know-how, tools), while they can retain the whole profit from the business. The above is a simple, linear contract (consisting of share and fixed pay), and more complex solutions are also known. From our point of view, though, it is important that under such contracts workers also enjoy a proportionate (not necessarily linear) share of the results of their efforts.

Still, the result of work does not the only depend on workers' efforts, it is also affected by other accidental factors. Thus, it can happen that on a bad day a worker's result and therefore their wage will be low due to reasons beyond their control, although they did their best and worked hard. Our bicycle courier could be standing in the rain waiting for orders for a whole day, if customers did not place orders on that day for some reason - the courier will earn nothing if there is no demand for their work. Workers face a risk: safe income is not guaranteed for them in return for a given effort. By sharing, which encourages more effort, both the result - the proportionate part of the economic profit - and part of the risk are also 
transferred from employers to the workers. In other words, employers source out their business risk too.

The role played by incentive contracts affecting uncertainty is less emphatic in the literature dealing with the gig economy. In a systematic review of the literature, Kaine-Josserand (2019) analysed 140 publications on the gig economy from 2009 to 2019. Based on a text-mining analysis, they designed a concept map and identified 69 research topics, but incentives were not among them. The concept of incentives is hardly present in the studies on the gig economy we referred to. Table 2 illustrates how many times the term 'incentive' appears in the studies we used. Of them, it is only Wu et al. (2019) that discuss incentives with some emphasis, while the topic is not present or only minimally present in the other studies. In the next chapter, the approach based on incentives cum risk is discussed: we intend to present the individual and social consequences of incentive performance-based wage and its concomitant uncertainty characterising the gig economy.

Table 2

Publications on the gig economy referred to in this paper and the relevant keywords*

\begin{tabular}{lccc}
\hline \multicolumn{1}{c}{ Studies } & Key words & $\begin{array}{c}\text { Term } \\
\text { 'Incentive' }\end{array}$ & $\begin{array}{c}\text { No of } \\
\text { words }\end{array}$ \\
\hline $\begin{array}{l}\text { Ashford et al. } \\
(2018)\end{array}$ & N/A & 0 & 15322 \\
\hline Berde (2020) & N/A & 0 & 4626 \\
\hline $\begin{array}{l}\text { Berde-Kuncz } \\
(2020)\end{array}$ & $\begin{array}{l}\text { platform economy, elderly drivers, } \\
\text { on-line survey, game theory model }\end{array}$ & 0 & 4164 \\
\hline $\begin{array}{l}\text { Berde-Tökés } \\
(2020)\end{array}$ & $\begin{array}{c}\text { Ride sharing, looking for work } \\
\text { on on-line platforms, number of internet clicks, } \\
\text { employment rate of the elderly }\end{array}$ & 0 & 5243 \\
\hline $\begin{array}{l}\text { Bergvall- } \\
\text { Karreborn- } \\
\text { Howcroft (2014) }\end{array}$ & $\begin{array}{c}\text { Amazon Mechanical Turk, crowdsourcing, } \\
\text { digital labour, outsourcing, platform, } \\
\text { crowd employment, ICT firms. }\end{array}$ & 0 & 5649 \\
\hline $\begin{array}{l}\text { Broughton et al. } \\
(2018)\end{array}$ & N/A & 6 & 14183 \\
\hline $\begin{array}{l}\text { Butler-Stoyanova } \\
\text { Russel (2018) }\end{array}$ & $\begin{array}{c}\text { creative labour, emotional labour, } \\
\text { freelance work, precarity, stand-up comedy }\end{array}$ & 2 & 9172 \\
\hline $\begin{array}{l}\text { Cachon et al. } \\
(2017)\end{array}$ & $\begin{array}{c}\text { self-scheduling capacity, peer-to-peer markets, } \\
\text { contract design, dynamic pricing, service } \\
\text { operations, ride sharing }\end{array}$ & 3 & 13799 \\
\hline $\begin{array}{l}\text { De Stefano (2015) } \\
\text { Drahokoupil- }\end{array}$ & N/A & 6 & 15843 \\
\hline Niasna (2019) & N/A & 639 \\
\hline
\end{tabular}




\begin{tabular}{|c|c|c|c|}
\hline Studies & Key words & $\begin{array}{c}\text { Term } \\
\text { 'Incentive' }\end{array}$ & $\begin{array}{l}\text { No of } \\
\text { words }\end{array}$ \\
\hline Friedman (2014) & $\begin{array}{l}\text { business fluctuations, labour economics, } \\
\text { labour policy, wage level and structure, } \\
\text { compensation packages, payment methods, } \\
\text { mobility, unemployment, turnover, vacancies, } \\
\text { lay-offs, unemployment insurance }\end{array}$ & 2 & 7503 \\
\hline $\begin{array}{l}\text { Goods et al. } \\
\text { (2019) }\end{array}$ & $\begin{array}{l}\text { Gig economy, job quality, platform work, } \\
\text { Post-Fordism, regulation }\end{array}$ & 2 & 9877 \\
\hline Gregory (2020) & $\begin{array}{l}\text { gig economy, platform labour, } \\
\text { risk, self-employment }\end{array}$ & 1 & 6913 \\
\hline Gyulavári (2019) & N/A & 2 & 10629 \\
\hline $\begin{array}{l}\text { Johnston et al. } \\
\text { (2018) }\end{array}$ & N/A & 1 & 20313 \\
\hline $\begin{array}{l}\text { Kaine-Josserand } \\
(2019)\end{array}$ & $\begin{array}{l}\text { digital platforms, gig economy, gig work, } \\
\text { on-demand work, text mining }\end{array}$ & 5 & 7412 \\
\hline $\begin{array}{l}\text { Katz-Krueger } \\
(2019)\end{array}$ & $\begin{array}{c}\text { alternative work arrangements, freelancers, } \\
1099 \text { economy, labour market flexibility, } \\
\text { temporary workers }\end{array}$ & 2 & 12788 \\
\hline Loveday (2018) & $\begin{array}{l}\text { anxiety, casualisation, governance, } \\
\text { higher education, neoliberalisation }\end{array}$ & 1 & 6871 \\
\hline $\begin{array}{l}\text { MacDonald- } \\
\text { Giazitzoglu } \\
(2019)\end{array}$ & $\begin{array}{l}\text { enterprise, gig economy, insecurity, precarity, } \\
\text { self-employment, Youth < Age groups }\end{array}$ & 0 & 6486 \\
\hline $\begin{array}{l}\text { Petriglieri et al., } \\
2019\end{array}$ & $\begin{array}{l}\text { work identity, emotion management, } \\
\text { holding environments, gig economy, } \\
\text { independent workers, systems psychodynamics, } \\
\text { individual agency }\end{array}$ & 0 & 19164 \\
\hline $\begin{array}{l}\text { Prassl-Risak } \\
(2016)\end{array}$ & N/A & 1 & 12761 \\
\hline $\begin{array}{l}\text { Stewart-Stanford } \\
(2017)\end{array}$ & $\begin{array}{l}\text { digital work, gig jobs, labour regulation, } \\
\text { precarity, risk }\end{array}$ & 0 & 6476 \\
\hline Wood (2018) & $\begin{array}{l}\text { discipline, flexibility, job insecurity, } \\
\text { labour process, scheduling, working time, } \\
\text { workplace control }\end{array}$ & 3 & 7208 \\
\hline $\begin{array}{l}\text { Wood et al. } \\
\text { (2019a) }\end{array}$ & $\begin{array}{l}\text { flexibility, gig economy, job quality, labour } \\
\text { process, platform economy, workplace control }\end{array}$ & 0 & 7073 \\
\hline $\begin{array}{l}\text { Wood et al. } \\
(2019 \mathrm{~b})\end{array}$ & $\begin{array}{l}\text { commodification, digital labour, embeddedness, } \\
\text { freelancing, gig economy, outsourcing, Polanyi }\end{array}$ & 3 & 7232 \\
\hline Wu et al. (2019) & $\begin{array}{l}\text { China, digital platform, gig work, } \\
\text { labour control, labour process }\end{array}$ & 24 & 9271 \\
\hline
\end{tabular}

Note: ${ }^{\star}$ How many words are in the studies (title, abstract and main text jointly) and how many times the term 'incentive' occurs (searching for incent- in English). 


\section{CHALLENGES}

The gig economy offers several opportunities, but you also have to face many new challenges. Some authors speak about a new world of work (e.g. Beck, 2014, Ashford et al., 2018). Individualism is strong in the gig economy due to the central position of contracts, as seen in individual, repeatedly renewed and usually incentive contracts used. That is why we were trying to use the singular when talking about workers, emphasising in that way the individualistic, individual-centred nature of the gig economy. In this chapter, we are dealing with the challenges of the gig economy that are the consequence of the tandem incentive-risk. We are starting out from problems at the individual level and proceed to reach social and economic issues.

A gig worker must face emotional and psychological challenges never experienced before. Ashford et al. (2018) identified the psychological challenges of gig workers originating from five structural features of gig economy: i) financial instability and job uncertainty, (ii) autonomy, (iii) career path uncertainty, (iv) work transience and (v) physical and relational separation. MacDonald-Giazitzoglu (2019) identified, among others, characteristic features of gig workers such as the lack of choice and control, insecurity of work, uncertainty of income, exploitation, self-exploitation and anxiety. We are also considering the above features of the gig economy in our analysis.

Because of contract employment, a gig worker's income is uncertain, so they feel like dancing at the edge of an abyss, they live in constant insecurity, feel anxiety about their future since they cannot rely on a stable basic income ensuring their everyday life. In addition, performance pay drives high competition, a gig worker must fight for their workday today. As the competition can take place on the internet, it can cross borders, can become global. For instance, a graphic artist in London may compete with a graphic artist in India for the same contract, while living expenses are highly different in the two locations resulting in further tension. (Broughton et al., 2018). Competition promotes commodification of work (Bergvall-Kåreborn-Howcroft, 2014, Wood et al., 2019b). Competing workers are less cooperative and become alienated and distanced from each other.

Not only their income but also their whole works are uncertain for gig workers. They can never be sure what, where and with whom they will work on any given day. Their whole work identity is questioned. They have no workplace relationships, therefore they are lonely, which is really frustrating. (Petriglieri et al., 2019). In their frustration they get alienated from their work, they are not loyal either to their employer, or their clients, or their mates, so they can hardly feel solidarity with other workers. 
The narrative of the gig economy suggests every man is for himself, so gig workers will feel they are alone and can only count on themselves. On the other hand, it is an advantage for gig work: gig workers are independent, their own bosses, and can shape the work-life balance freely and flexibly. For many gig workers, however, this independence and freedom is a tinsel show. The terms 'forced entrepreneurship' and 'bogus self-employment' mentioned earlier are linked to that phoney freedom. Workers have the feeling that, in fact, employers - that appear in the form of a faceless algorithm in many cases - have totally taken control over their lives (Wood et al., 2019a). And in fact, as it has been presented in the previous chapter on the model of principal and agent, in the lack of regulations employers can use incentive contracts to exercise their will and control their workers (Wood, 2018; Wu et al., 2019). Our bicycle courier described earlier would like in vain to work no more than two hours on a given day due to their exams at university - what he could do in theory - the reality is an incentive contract compiled in line with the employer's goals will punish them if they do not agree to take a minimum six-hour shift. Most gig workers report long shifts and hourly wages below the minimum wage as well as unexpected pressure (Broughton et al., 2018). Freedom is but an illusion for gig workers dependent on contracts, economic pressure, exploited or self-exploiting in many cases.

In traditional permanent employment, when workers are part of an organisation, they only have to deal with their own tasks, their own work. Workers do not have to care about the operation of the infrastructure, the sale of products or business risk, as they are the duties of the organisation to be solved in return for the workers' commitment and loyalty. On the other hand, such duties make up a significant part of gig workers' time: they have to manage the infrastructure needed for their work, they have to find more and more jobs, they have to promote themselves, in other words, they have to sell themselves (Ashford et al., 2018), which is related to the issues of commodification. Such activities not directly related to their work consume a lot of energy, which reduces productibility. Further, Friedman (2014) mentions that during their work gig workers consume their human capital accumulated earlier. While in traditional employment employers will spend on developing their workers' skills, a similar development of human resources is not present in the gig economy. While workmates in a traditional organisation will help each other, and knowledge transfer is present, it is practically non-existent in the gig economy. All that is still worth for employers, because they have outsourced almost all their duties and reduced their expenses and risk. Although productivity and output decline, employers still get a bigger slice of the smaller cake as a result of the workers' vulnerability.

Employers transfer risk to their workers by incentive contracts. And risk exactly is what an individual is most vulnerable to. Risk or uncertainty are difficult to 
understand, process, manage and put a price-tag on at individual level. Employers often play it up by advertising you can reach such and such income doing gig work. They lure workers by presenting the highest short-term wage attainable in the most optimistic scenario and not the long-term average income to be expected.

Gig economies are under-regulated all over the world. The law regards gig workers as independent contractors and assumes their relationship with employers is one of two equal parties having equal bargaining power. Thus, employment rules do not apply to gig workers, there are no restrictions on working hours, no rules on pay, no protection, no paid holidays or sick leave and no entitlement to pension (Stewart-Stanford, 2017, Broughton et al., 2018).

The individual nature of the gig economy is not favourable for workers' interest assertion. Johnston et al. (2018) wrote about workers' self-organisation, interest assertion and the possibility of trade unions. As collective spirit is forced into the background, workers' self-organisation becomes almost impossible. On the one hand, most of them have no connection with their mates as work changes all the time - even the term 'colleague' becomes almost incomprehensible in the gig economy. On the other hand, performance pay does not encourage workers to collaborate. With no collective spirit, the bargaining power of gig workers is low compared to their employers' in possession of information, the most valuable of resources.

\section{CONCLUSIONS}

It has been illustrated above how short-term incentive contracts place major uncertainty and risk on workers. Although it is true that the gig economy as outlined in the previous chapters has a number of novel aspects compared to traditional work arrangements, such as collecting and processing information and organising work on the internet, contract-based employment transferring risk to workers is not a novelty at all.

Contract based employment has had a centuries-old history in agriculture. The form of work organisation termed 'sharecropping' in the literature operated on the mechanism of incentive and risk introduced earlier (Stiglitz, 1974; Reid, 1975). In it, a landowner granted a worker a small plot to cultivate (typically for a year) in exchange for a fixed lease fee and/or share in the crops. A study by Stiglitz'Incentives and risk sharing in sharecropping' (1974) is a good example for the analysis of the part played by incentives.

In Hungary, the institution of land lease was less common, but the mechanism of share-harvesting in the 18th and 19th centuries (Katona, 1961) where workers 
received a share of the crops harvested was quite similar from the aspect of incentives and risk. The terms piecework, lump-sum work, day labour and gang work are all related to the concept of share work described in the Hungarian Ethnographic Lexicon edited by Gyula Ortutay (Ortutay, 1981) as follows:

"agricultural contract work, farm work, chord work

A type of contract work when workers (agricultural and industrial contract workers) receive their predetermined (usually cash) salary for the amount of material extracted or processed (wood, land, coal, agricultural or industrial products etc). Measurement can be based on pcs number (e.g. shearing animals), weight (crumbs), area (beet picking), cubic content (digging). It is more modern than traditional part-time work and much more stimulating than similar fallback work; together with these two it belongs to the group of performance pay work while day labour, for instance, is time-based and gang work is of a mixed type. (Those terms are not used in the literature uniformly)..." (Katona, 1981, bold set by the author).

Such work arrangements that have been present for centuries perfectly match our concept of the gig economy. With respect to the nature of their work, bicycle couriers are no different from share harvesters or day labourers. Those who can pedal twice as fast or pick fruits twice as fast will earn twice as much. As the gig economy is gaining momentum, it is no surprise that the ratio of seasonal work and day labour in agriculture has also been growing in Hungary ovr the past decade (Hamar, 2016).

The old-new world of the gig economy is built on vulnerable workers. According to the philosophy of the gig economy, work contracts are the result of negotiations between equal parties. In reality, however, employers offering incentive contracts, performance pay and passing on risk exploit the other party whose bargaining power is low, who live from day to day and who are at a disadvantage. Although the gig economy is flexible, that flexibility mostly benefits the employers to the detriment of the workers. As MacDonald és Giazitzoglu worded it, „from the point of view of these workers, 'flexibility' was a euphemism for exploitation" (MacDonald-Giazitzoglu [2019] p. 733). Standing (2014) identified a new social class of uncertainty as their basic experience, which he termed precariat. MacDonald-Giazitzoglu (2019) argue the gig economy is just an example of the wider and more general phenomenon of precarity that has been present in neo-liberal post-capitalist societies for decades. Our incentive-risk approach supports that argument $^{2}$. As described earlier, the main difficulties of gig workers are caused

2 It should be noted that STANDING (2011) differentiates the class of sole traders and free-lancers (termed proficians) from precariat, which notions are not divided in our concept of the gig economy. 
by the uncertainty of their income and work which originate from incentive contracts. Due to their vulnerability and low bargaining power, workers must enter the gig economy and take almost all risks over from their employers. It is in gig workers' basic interest to slip some kind of stability into the gig economy, which is changing all the time, to reduce vulnerability and increase security.

To reduce gig workers' vulnerability, working conditions must be regulated beginning from set working hours through paid holidays and minimum wages to unemployment benefits. With the introduction of proper labour law provisions and welfare systems you can achieve that workers should not be forced to accept gig work under any exploiting conditions. Stewart-Stanford (2017) analyses the options to regulate gig economy. The authors identify five main lines of action: (i) enforcement of existing laws, (ii) clarifying or expanding definitions of employment, (iii) creating a new category of independent worker, (iii) creating rights for workers not employees, and (iv) reconsidering the concept of an employer. They urge regulators to be creative and ambitious in better protecting the minimum standards and conditions of workers in these situations.

\section{SUMMARY}

In this paper we discussed the background of the spreading gig economy. Our analysis was focused on the relationship of gig workers and employers and the incentive contracts defining it. We illustrated the mechanism of incentive-risk arising from short-term contracts neglecting workers' rights using the model of principal-agent. We looked at the psychological and social issues appearing as a result of uncertainty forced onto workers by employers via their contracts and extreme individualism. Reviewing the historical forerunners of the gig economy, such as sharecropping or farm day labour, we have realised this exploiting world of work built on vulnerability is not so new, it is rather old-new. The gig economy has been linked to the social theory of precariat. The necessity of regulating the gig economy and the importance of workers' rights has been raised.

Hidden behind the call words of freedom and flexibility, incentives in the gig economy are nothing but outsourcing business risk, control over the workers and the exploitation of labour. Gig workers have the best chance to improve their position if they can break with the extreme individualism of the gig economy and strengthen cooperation and the collective spirit. 


\section{REFERENCES}

Ashford, Susan J. - Caza, Brianna. B. - Reid, Erin M. (2018): From surviving to thriving in the gig economy: A research agenda for individuals in the new world of work. Research in Organizational Behavior, 38, 23-41. https://doi.org/10.1016/j.riob.2018.11.001

BeCK, UlRICH (2014): The brave new world of work. Polity Press, Cambridge, UK. ISBN 0-7456-2397-2

BERDE, Éva (2020): A sztenderd munkavégzés versus nem sztenderd munkavégzés [Standard versus non-standard work]. Új Munkaügyi Szemle, 1(1), 17-29.

Berde, Éva - Kuncz, Izabella (2020): Ha elmúlt ötvenöt éves, megmondja az életkorát? - Az Oszkár-soförök viselkedésének modellezése [Will you tell your age if you are over fifty? - Modelling the behaviour of Oscar drivers]. Alkalmazott Matematikai Lapok, 37(2), 195-210 o. https:// doi.org/10.37070/AML.2020.37.2.05

Berde, Éva - TőkÉs, LÁszló (2020): Platformokon keresztül dolgozó idősebb munkavállalók. Az Oszkár utazásmegosztó példája [Elderly employees working via platforms. Example of Oscar]. Köz-Gazdaság, ONLINE FIRST, http://unipub.lib.uni-corvinus.hu/4713/.

Bergvall-Kåreborn, Birgitta - Howcroft, Debra (2014): Amazon Mechanical Turk and the commodification of labour. New Technology, Work and Employment, 29(3), 213-223. https://doi. org/10.1111/ntwe.12038.

Broughton, Andrea - Gloster, Rosie - Marvell, Rosa - Green, Martha - Langley, Jamal - Martin, Alex (2018): The experiences of individuals in the gig economy. HM Government, Department for Business, Energy and Industrial Strategy. https://www.gov.uk/government/ publications/gig-economy-research.

Butler, Nick - Stoyanova Russell, Dimitrinka (2018). No funny business: Precarious work and emotional labour in stand-up comedy. Human Relations, 71(12), 1666-1686. https://doi. org/10.1177\%2Fo018726718758880.

Cachon, Gérard - Daniels, Kaitlin M. - Lobel, Ruben (2017): The role of surge pricing on a service platform with self-scheduling capacity. Manufacturing \& Service Operations Management, 19(3), 368-384. https://doi.org/10.1287/msom.2017.0618.

De Stefano, Valerio (2015): The rise of the just-in-time workforce: On-demand work, crowdwork, and labor protection in the gig-economy. Comp. Lab. L. \& Pol'y J., 37, 471-504.

Drahokoupil, JAN - PiAsna, Agnieszka (2019): Work in the platform economy: Deliveroo riders in Belgium and the SMart arrangement. ETUI Research Paper-Working Paper. https://papers.ssrn. $\mathrm{com} / \mathrm{sol}_{3} /$ papers.cfm?abstract_id=3316133.

FRIEDMAN, GERALD (2014): Workers without employers: shadow corporations and the rise of the gig economy. Review of Keynesian Economics, 2(2), 171-188. https://doi.org/10.4337/roke.2014.02.03.

Goods, Caleb - Veen, Alex - Barratt, Tom (2019): “Is your gig any good?” Analysing job quality in the Australian platform-based food-delivery sector. Journal of Industrial Relations, 61(4), 502-527. https://doi.org/10.1177\%2Fo022185618817069.

Gregory, Karen (2020): 'My life is more valuable than this': Understanding risk among on-demand food couriers in Edinburgh. Work, Employment and Society, 35(2), 316-331. https://doi. org/10.1177\%2F0950017020969593

GyUlaVÁRI, TAMÁs (2019): Haknigazdaság a láthatáron: Az internetes munka fogalma és sajátosságai [Gig economy on the horizon: the concept and features of internet work]. Iustum Aequum Salutare, 15, 25-51.

Hamar, ANNA (2016): Idénymunka a zöldség-gyümölcs ágazatban [Seasonal work in the fruit and vegetable sector]. In Kovács, Katalin (ed.): Földből élők: Polarizáció a magyar vidéken [Living off the land: polarisation in the Hungarian countryside]. Budapest: Argumentum Kiadó, 93-111. ISBN 978-963-446-773-1. 
Huws, Ursula - Spencer, Neil - Coates, Matthew - Sverre Syrdal, Dag - Holts, Kaire (2019): The platformisation of work in Europe: Results from research in 13 European countries. University of Hertfordshire. https://doi.org/10.18745/ds.216oo.

IVANCHEVA, MARIYA (2015): The age of precarity and the new challenges to the academic profession. Studia Universitatis Babes-Bolyai-Studia Europaea, 6o(1), 39-48.

Jensen, Michael C. - Meckling, William H. (1976): Theory of the firm: Managerial behavior, agency costs and ownership structure. Journal of Financial Economics, 3(4), 305-36o. https://doi. org/10.1016/0304-405X(76)90026-X.

Johnston, Hannah - LAnd-Kazlauskas, Chris (2018): Organizing on-demand: Representation, voice, and collective bargaining in the gig economy. Conditions of work and employment series, 94.

Kaine,SARAh-Josserand,Emmanuel (2019): Theorganisation and experienceofworkin thegigeconomy. Journal of Industrial Relations, 61(4), 479-501. https://doi.org/10.1177\%2Fo022185619865480

KatonA, ImRe (1961): Munkaszervezeti formák és ideiglenes életközösségek idénymunkákon a kapitalizmus korában [Forms of work organisation and temporary communities on seasonal jobs in the age of capitalism]. Agrártörténeti Szemle, 3-4, 534-562.

Katona, Imre (1981): szakmánymunka [piece work]. In Ortutay Gyula (ed., 1981): Magyar Néprajzi Lexikon IV. kötet [Hungarian Ethnography Lexicon, Vol. 4]. Budapest: Akadémiai Kiadó, ISBN 963-05-1289-0.

Katz, Lawrence. F. - Krueger, Alan. B. (2019): The rise and nature of alternative work arrangements in the United States, 1995-2015. ILR Review, 72(2), 382-416. https://doi. org/10.1177\%2Foo19793918820008.

LovedAy, Vik (2018): The neurotic academic: Anxiety, casualisation, and governance in the neoliberalising university. Journal of Cultural Economy, 11(2), 154-166. https://doi.org/10.1080/1753035 0.2018 .1426032

MacDonald, Robert - Giazitzoglu, Andreas (2019): Youth, enterprise and precarity: or, what is, and what is wrong with, the 'gig economy'? Journal of Sociology, 55(4), 724-740. https://doi. org/10.1177\%2F1440783319837604.

Ortutay, Gyula (szerk., 1981): Magyar Néprajzi Lexikon IV. kötet [Hungarian Ethnography Lexicon, Vol. 4]. Budapest: Akadémiai Kiadó, ISBN 963-05-1289-o.

Petriglieri, Gianpiero - Ashford, Susan. J. - Wrzesniewski, Amy (2019): Agonyand ecstasyin the gig economy: Cultivating holding environments for precarious and personalized work identities. Administrative Science Quarterly, 64(1), 124-170. https://doi.org/10.1177\%2Fooo1839218759646.

Prassl, Jeremias - Risak, Martin (2015): Uber, taskrabbit, and co.: Platforms as employers-rethinking the legal analysis of crowdwork. Comp. Lab. L. \& Pol'y J., 37, 619-651.

Reid, Joseph D. (1975): Sharecropping in history and theory. Agricultural History, 49(2), 426-440. https://www.jstor.org/stable/3741281

Standing, Guy (2011): The Precariat - The new dangerous class. London: Bloomsbury Academic, ISBN 978-1-84966-352-6.

Stewart, Andrew - Stanford, Jim (2017): Regulating work in the gig economy: What are the options? The Economic and Labour Relations Review, 28(3), 420-437. https://doi. org/10.1177\%2F1035304617722461

Stiglitz, Joseph E. (1974): Incentives and risk sharing in sharecropping. The Review of Economic Studies, 41(2), 219-255. https://doi.org/10.2307/2296714.

Wood, Alex J. (2018): Powerful times: Flexible discipline and schedule gifts at work. Work, Employment and Society, 32(6), 1061-1077. https://doi.org/10.1177\%2Fo950017017719839 
Wood, Alex J. - Graham, Mark - Lehdonvirta, Vili - Hjorth, Isis (2019a): Good gig, bad gig: Autonomy and algorithmic control in the global gig economy. Work, Employment and Society, 33(1), 56-75. https://doi.org/10.1177\%2Fo950017018785616.

Wood, Alex J. - Graham, Mark - Lehdonvirta, Vili - Hjorth, Isis (2019b): Networked but commodified: The (dis)embeddedness of digital labour in the gig economy. Sociology, 53(5), 931950. https://doi.org/10.1177\%2Foo38038519828906.

Wu, Qingjun - Zhang, Hao - Li, Zhen - LiU, Kai (2019): Labor control in the gig economy: Evidence from Uber in China. Journal of Industrial Relations, 61(4), 574-596. https://doi. org/10.1177\%2Foo22185619854472. 